\title{
the conundrum in the collective indian psyche regarding teaching philosophy in schools
}

\author{
arvind venkatasubramanian ${ }^{1}$ \\ amrita vishwa vidyapeetham university, india \\ orcid id: https:// orcid.org/0000-0003-3140-2451
}

\begin{abstract}
India now constitutes approximately $17 \%$ of the world's population and has a high proportion of younger people. Philosophy for school children aims to create better citizens of the future. In this article, I establish the need to teach philosophy to children in schools, especially in India. Subsequently, I discuss the readiness of Indians to accept philosophy in the school curriculum, their conundrum in understanding the need for philosophy in a school setting, and the EastWest dilemma concerning the teaching of philosophy in schools. The concept of self-realization is important in education. Socrates claimed that an unexamined life is not worth living. However, the self-realization concept of the West differs from that in India. While the former perceives self-realization as a way to construct a good individual, the latter has always emphasized the cessation of the individual and focused on the incomprehensible truth human languages cannot capture. Western philosophy is concerned with questioning, inquiry, and the problems of philosophy. The East is concerned with bringing such questioning to an end. Matthew Lipman focuses on increasing curiosity, accelerating the thinking process, teaching logic and formal reasoning, and the intellectual enhancement of children. Indian philosophy, yoga, and meditation are all concerned with the cessation of consciousness. The key question concerns the approach one may choose to adopt in teaching philosophy - accelerating or decelerating the thought processes of children? Indian parents are the primary decision-makers in their children's education, and sometimes throughout their careers and lives. Unless clarity emerges in the Indian and global community regarding this issue, there is no clear starting point for teaching philosophy to children in India. This article aims to raise critical awareness among global citizens regarding this conundrum in the collective Indian psyche. Unless the world's psyche is inserted into the place of the Indian psyche, the great barrier between the West and the East regarding philosophy in the school curriculum cannot be bridged.
\end{abstract}

keywords: philosophy and childhood; yoga and meditation; patanjali; indian philosophy; lipman.

\section{o enigma na psique coletiva indiana em relação ao ensino de filosofia nas escolas}

\section{resumo}

A Índia agora constitui aproximadamente $17 \%$ da população mundial e tem uma alta proporção de pessoas mais jovens. A filosofia para crianças em idade escolar visa criar melhores cidadãos do futuro. Neste artigo, estabeleço a necessidade de ensinar filosofia para crianças nas escolas, especialmente na Índia. Posteriormente, discuto a disposição dos indianos em aceitar a filosofia no currículo escolar, seu enigma na compreensão da necessidade da filosofia no ambiente escolar e o dilema Leste-Oeste a respeito do ensino de filosofia nas escolas. O conceito de autorrealização é importante na educação. Sócrates afirmou que uma vida não examinada não vale a pena ser vivida. No entanto, o conceito de autorrealização do Ocidente difere daquele da Índia. Enquanto o primeiro percebe a autorrealização como uma forma de construir um bom indivíduo, o segundo sempre enfatizou a cessação do indivíduo e

\footnotetext{
${ }^{1}$ E-mail: mdu.arvind@gmail.com
} 
se concentrou na verdade incompreensível que as linguagens humanas não conseguem captar. A filosofia ocidental está preocupada com o questionamento, a investigação e os problemas da filosofia. O Oriente está preocupado em encerrar esse questionamento. Matthew Lipman se concentra em aumentar a curiosidade, acelerando o processo de pensamento, ensinando lógica e raciocínio formal e o aprimoramento intelectual das crianças. A filosofia, ioga e meditação indianas estão preocupadas com a cessação da consciência. A questão-chave diz respeito à abordagem que se pode escolher adotar no ensino de filosofia - acelerar ou desacelerar os processos de pensamento das crianças? Os pais indianos são os principais tomadores de decisão na educação de seus filhos e, às vezes, ao longo de suas carreiras e vidas. A menos que haja clareza na comunidade indiana e global em relação a esse assunto, não há um ponto de partida claro para o ensino de filosofia para crianças na Índia. Este artigo tem como objetivo aumentar a consciência crítica entre os cidadãos globais sobre esse enigma na psique coletiva indiana. A menos que a psique do mundo seja inserida no lugar da psique indiana, a grande barreira entre o Ocidente e o Oriente em relação à filosofia no currículo escolar não pode ser transposta.

palavras-chave: filosofia e infância; ioga e meditação; patanjali; filosofia indiana; lipman.

\section{el enigma en la psique colectiva de la india con respecto a enseñar filosofía en las escuelas}

\section{resumen}

La India constituye actualmente aproximadamente el 17\% de la población mundial y tiene una elevada proporción de jóvenes. La filosofía para los estudiantes en escuelas tiene como objetivo crear mejores ciudadanos del futuro. En este artículo, establezco la necesidad de enseñar filosofía a los niños en las escuelas, especialmente en la India. Posteriormente, analizo la disposición de los indios a aceptar la filosofía en el programa escolar, su enigma para comprender la necesidad de la filosofía en un entorno escolar y el dilema Este-Oeste relativo a la enseñanza de la filosofía en las escuelas. El concepto de autorrealización es importante en la educación. Sócrates afirmó que una vida no examinada no vale la pena vivirla. Sin embargo, el concepto de autorrealización de Occidente difiere del de la India. Mientras que el primero percibe la autorrealización como una forma de construir un buen individuo, el segundo siempre ha hecho hincapié en el cese del individuo y se ha centrado en la verdad incomprensible que los idiomas humanos no pueden captar. La filosofía occidental se ocupa del cuestionamiento, la indagación y los problemas de la filosofía. El Oriente se preocupa por poner fin a ese cuestionamiento. Matthew Lipman se centra en aumentar la curiosidad, acelerar el proceso de pensamiento, enseñar la lógica y el razonamiento formal, y la mejora intelectual de los niños. La filosofía india, el yoga y la meditación se ocupan del cese de la conciencia. La pregunta clave se refiere al enfoque que uno puede elegir para enseñar la filosofía: ¿acelerar o desacelerar los procesos de pensamiento de los niños? Los padres indios son los principales responsables de la toma de decisiones en la educación de sus hijos, y a veces a lo largo de sus carreras y vidas. A menos que surja claridad en la comunidad india y mundial con respecto a esta cuestión, no hay un punto de partida claro para la enseñanza de la filosofía a los niños en la India. El presente artículo tiene por objeto aumentar la conciencia crítica de los ciudadanos del mundo respecto de este enigma de la psique colectiva india. A menos que la psique del mundo se inserte en el lugar de la psique india, no se podrá salvar la gran barrera entre Occidente y Oriente en lo que respecta a la filosofía en el programa escolar.

palabras clave: filosofía e infancia; yoga y meditación; patanjali; filosofía india; lipman. 
the conundrum in the collective indian psyche regarding teaching philosophy in schools

\section{introduction}

Jean Piaget's theory of cognitive development suggests that philosophical thinking, such as metacognition, is not possible in most children aged below 11-12. His theory proposes 4 stages of cognitive development, the $4^{\text {th }}$ of which is the "formal operational" stage where higher-order thinking is possible. However, philosophers such as Gareth Mathews and Michael Pritchard provided a strong body of evidence against this theory. ${ }^{2}$ For instance, Pritchard observed philosophical dialogues taking place between school children aged 7-11, which Piaget characterizes as a concrete operational stage where abstract reasoning is impossible. ${ }^{2}$ Children and teachers now have a heavy workload at schools and parents put pressure on children to succeed academically. Academic success is viewed as synonymous with educational success. Introducing philosophy into the school curriculum therefore constitutes an additional burden as countries are also racing to introduce artificial intelligence and machine learning into the school curriculum. By introducing philosophy, students will be afforded an opportunity to reflect on relationships among different areas of inquiry or disciplines of knowledge and experience meaningful education. Philosophy also enhances skills such as reasoning ability and critical thinking which will aid selfregulated learning and metacognition. The result is increased knowledge and levels of attainment across all disciplines taught at school. ${ }^{2}$

Lipman initiated the philosophy for children (p4c) movement in the USA. It has been successful in several Western countries and continues to grow. However, In India, there is no societal demand for philosophy to be taught at the school level. The country is struggling to address high levels of corruption, and the present society is far from appreciating a philosophy of life, let alone teaching this in schools. Nevertheless, there has to be a starting point somewhere, and this article is written in the hope of initiating

\footnotetext{
${ }^{2}$ https:/ / plato.stanford.edu/entries/children/
} 
this. Notably, in the Vedic period (1500 BC and $600 \mathrm{BC}$ ) and the Buddhist period in India, philosophy was a major subject for school children aged 8 and onwards. The mediums of instruction during those times were Sanskrit, Prakrit, Pali, and local vernacular languages. Although both the West (Plato's Academy) and East (India) taught philosophy in schools at different periods, there were major differences in their contents and approaches. This paper highlights such differences and identifies a way forward for schoolteachers in teaching philosophy, and emphasizes the importance of doing so in terms of the overall benefits to human civilization.

\section{justification of the article theme}

Listed next are some of the problems humanity has created for itself. These are:

- Environmental problems - air/water/soil/chemical/noise/plastic/ocean pollution, highly polluted cities, a harmful hole in the ozone layer, use of pesticides/fungicides in agriculture, and a lack of quality food due to profit-oriented private merchandise.

- Depletion of natural resources: population explosion, reduction in the quantity of nonrenewable natural resources (peak oil), deforestation, unevenly distributed rainfall, climate change, global warming, rising sea levels, disposal of plastic water bottles, migration of refugees inland and outside, excessive killing of animals for meat exports, loss of biodiversity, flora and fauna, more farmer/student suicides (in India and other developing nations).

- Violence and anger: child (sex) trafficking, abduction of women, child rape ${ }^{3}$, poverty, adolescent lives blighted by confusion, psychological strife and stress, increases in crime and violence, the threat of nuclear war, the dangers of weapons, national border disputes, use of the army, military and navy, organized violence relating to border issues, biological warfare, civil wars, wars for natural resources, terrorism and insurgency,

\footnotetext{
${ }^{3}$ https://newsable.asianetnews.com/india/ 8-teachers-videograph-rape-13-year-old-for-two-yearsbikaner-rape
} 
- Natural calamities - an increase in earthquakes, forest fires, tsunamis, floods and hurricanes

- Financial crises - greater levels of corruption and money laundering inside government machineries, imbalance in economic distribution of wealth, economic breakdowns (Euro crisis, recessions, and stock market crashes)

- Family Problems - children's addiction to mobile phones and television, a higher number of divorce cases, broken families, unhealthy/illegal relationships, gender disparities $^{5}$

- Health problems - the emergence of new diseases (SARS-2, MERS, COVID-19), more young patients admitted to hospital for blood pressure, sugar and cardiac problems, diabetes, cancer, Alzheimer's disease, the poor not being able to access health/educational services, water scarcity, water/air pricing, profit-oriented educational industry, eating junk foods, increasing rates of alcoholism, addiction to cigarettes and tobacco, drug usage, bodies getting weaker day by day ${ }^{6}$, the harmful effects of genetically modified food, multinational corporate monopolies of naturally occurring seeds,

- Entertainment prioritized over life issues: addiction to excessive entertainment, narcissism and problematic social media use ${ }^{7}$, irrelevant content (e.g., sports matches) on TV and social media considered more important by the public than the portrayal of burning issues such as domestic violence/murder, cybercrime.

- Distrust in governments: scandals in democratic elections, misuse of digital data, extreme nationalism and chauvinism, non-trust in government machineries ${ }^{8}$, leaks of classified documents revealing government irresponsibility, a relentless march towards a $6^{\text {th }}$ mass extinction.

\footnotetext{
${ }^{4}$ https://www.ncbi.nlm.nih.gov/pmc/articles/PMC4555288/

${ }^{5}$ https://unesdoc.unesco.org/ark:/48223/pf0000146763

${ }^{6}$ https://www.voanews.com/silicon-valley-technology/study-modern-humans-are-weaker-ancestors

${ }^{7}$ https:// www.sciencedirect.com/science/article/pii/S2352853219302391

8 https://scholars.org/sites/scholars/files/ssn_key_findings_fried_on_distrust_in_government.pdf
} 
There seems to be a 'loss of humility' in human beings even though humans generally claim that they are humble. Without thoughts, all the above mentioned human actions are impossible. This clarifies that human thoughts are the root cause of all these problems. The actions that are borne out of human thought patterns do not seem to fashion a coherent and tolerable civilization. ${ }^{9}$ Conversely, it can be argued that numerous noble ideas have emerged out of human thought. People can also feel and experience coherence when using thoughts to guide their daily lives. This is undeniable; human thought has been used to generate nuclear energy as well as nuclear bombs. Thought underpins children's education. Hence, our educators and governments need to be careful with the thinking they present to children - which means they must carefully monitor their own thoughts. Bohm (1994) rejects the notion that our thinking processes neutrally report on what is 'out there' in an objective world. He explores the manner in which thought actively participates in forming our perceptions, our sense of meaning, and our daily actions. He suggests that collective thought and knowledge are so automatic that individuals are largely controlled by them, resulting in a subsequent loss of authenticity, freedom and order. ${ }^{9}$

"It is only when the mind is completely still that there is a possibility of touching the deep waters"10. - Jiddu Krishnamurti

A still mind is nothing but a 'thoughtless mind.' Therefore, it is clear that the nature of human thought needs to be investigated, given that these form the basis of education at all levels. However, the only tool available to study thought is thought. It must therefore be accepted that philosophy is essential in school education. This issue is complicated by the fact that the world is divided into paradigms. Western philosophy is rooted in reasoning, logic, and critical thinking. By contrast, Indian philosophy, although it has sufficient scope for reasoning and arguments, is ultimately interested in the cessation of thoughts or consciousness of an individual.

9 David Bohm's statements from abstract portion of "Thought as a system" (1994) https:// books.google.co.in/books/about/Thought_as_a_System.html?id=Nj77486SOyMC\&redir_esc= y

${ }^{10}$ https://www.kfionline.org/online-store/on-mind-and-thought/ 


\section{the ancient indian philosophical approach for school children - patanjali}

Indian philosophy was taught in schools during the Vedic period in the Indian subcontinent. These were divided into astika (Vedas as authority) schools and nastika schools that did not subscribe to Vedas. Nyaya (logic-epistemology) and Yoga ${ }^{14}$ were among the small number of systems with astika Indian philosophy. Buddhism and Jainism belonged to nastika thought.

India possessed all forms (branches) of philosophical knowledge bar the modern developments that have taken place in Western philosophy over the last 200-300 years. India also prospered in science, mathematics, astrology, literature, and medicine during these times. There may therefore have been a constant exchange of knowledge between India and its ancient Western counterparts (Greece, Rome) (McEvilley, 2002). The Sanskrit term "upaniṣhad", which means "sitting down near", refers to the student sitting down near the teacher to receive spiritual knowledge (see Radhakrishnan \& Moore, 1960). Upanișhad laid the foundations for yoga, implying that the self can only be known through union (yoga) and not by speculation and learning. However, Upanishads do not offer a systematic treatment and summary of the paths of yoga (see Srinivasan, 2015). This could be because self-realization is not necessarily a systematic process. The Indian scriptures ranging from Vedas (which communicated a truthful direct message) to Indian epics ${ }^{11}$ and Purana stories (diluted for the understanding of masses) have only one common objective: self-realization. Therefore, the purpose of Indian education is also self-realization.

For this article, I have chosen to focus on yoga philosophy for the education of children as it involves integrated practices for the overall development of mind and body that are suitable for this age group. At Gurukula, alongside yoga-meditation, children were successfully taught philosophy using Indian epics, yoga vasistha sara (see Ramanasramam, 1999), Subhashitas (Shruthi \& Rajani Jairam, 2016) and

\footnotetext{
${ }^{11}$ https://www.britannica.com/topic/Ramayana-Indian-epic
} 
Panchatantra fables.12 Shubhashitas are short ancient messages that convey human values and are easy to memorize and recall. Yoga refers to the cessation of movements in consciousness. ${ }^{13}$ There are numerous paths of yoga [Karma (action), bhakthi (emotion), jnana (intellect), Hatha (willpower), and raja (mind) yoga], all with different purposes; however, when they progress, they merge towards self-realization. External yoga includes preventing injuries, self-discipline, postures, breathing techniques, and withdrawal of senses. ${ }^{13}$ Internal yoga includes maintaining a focus on one external object, meditation with concentration, and samadhi ${ }^{13}$ (cessation of consciousness or release from the cycle of rebirth/karma). ${ }^{14}$ Yoga is often misunderstood as belonging to the Hindu religion. However, Hinduism was not a religion ${ }^{15}$, but a fine-tuned lifestyle geared toward self-realization. Yoga has no affiliation to any religion; it is universal. The Patanjali yoga sutra has 4 chapters $^{13}$ containing aphorisms on contemplation, practice, mind control, meditation stages, superhuman powers, and emancipation (see Aranya, 2000) which correspond to 4 purusarthas (the aim of life), as described in Table 1.

Table 1: Four purusarthas of life

\begin{tabular}{|c|c|c|}
\hline Purusarthas & Objective & Adolescents should \\
\hline Dharma $^{16}$ & $\begin{array}{l}\text { Goal of life, importance of study, } \\
\text { adolescent problems, and ways to form } \\
\text { good relationships with parents, } \\
\text { society, and teachers and to have } \\
\text { overall health. }\end{array}$ & $\begin{array}{l}\text { Inquire and act according to } \\
\text { life situations and context } \\
\text { without confusion in the } \\
\text { mind. }\end{array}$ \\
\hline
\end{tabular}

\footnotetext{
12 https://www.britannica.com/topic/Panchatantra-Indian-literature

13 https://iep.utm.edu/yoga/

14 https:// www.britannica.com/topic/Yoga-philosophy

15 https://www.britannica.com/topic/Hinduism

16 https://www.britannica.com/topic/dharma-religious-concept
} 


\begin{tabular}{|l|l|l|}
\hline Artha ${ }^{17}$ & $\begin{array}{l}\text { Set a material aim to become a } \\
\text { successful person. }\end{array}$ & $\begin{array}{l}\text { Practice emotional control - } \\
- \text { work on mental } \\
\text { fluctuations. }\end{array}$ \\
\hline Kama & Control the extremes -- likes \& dislikes & \multicolumn{1}{|c|}{ Work on Astanga yoga ${ }^{14}$} \\
\hline Moksha & $\begin{array}{l}\text { Freedom from the mind's obstacles will } \\
\text { lead to self-awareness }\end{array}$ & \\
& & \\
\hline
\end{tabular}

In most adolescents, bodily organs, muscles, and nerves are not in harmony and work in an incoherent fashion. The endocrine system becomes irregular and the efficiency of the nervous system decreases, which results in diseases. This can be controlled by yoga which brings the body back to a state of harmony. Yoga aims for complete control of the mind. To understand the states of mind, one first has to understand the trigunas. ${ }^{13}$ All human beings are born with a balanced mix of these trigunas and all objects around us have trigunas (three characteristics of man). Tamas ${ }^{18}$ implies a state of darkness, inertia, and ignorance. Rajas ${ }^{18}$ implies energy, action, change, and movement. Individuals with rajas have a mixture of anger, anxiety, fear, irritation, chaos, and are always success seekers. Sattva ${ }^{18}$ is the most desired quality. It refers to the blissful state of saints with reduced tamas and rajas. It implies being in a state of harmony, balance, joy, and intelligence. Trigunas shape the following five states of mind. The muha or muddha state (donkey minded) is dull, sleepy, and lethargic. Kshiptha (restless monkey mind) is a mind without concentration, fluctuating from one thought/emotion/object to another. The vikshipta (occasionally steady butterfly mind) is tentatively distracted/focused; the mind thus oscillates between clarity and confusion. Ekagra (one-pointed candle mind) remains focused on one object; the mind is extremely relaxed but not sleepy. The final state of mind, Niruddha ${ }^{18}$ (cessation of consciousness), is not distracted by random thoughts and concentrates fully. Although most people remain in the first 3 states, only the final two

\footnotetext{
17 https://www.britannica.com/topic/artha

18 http://www.kkhsou.in/main/philosophy/yoga_psychology.html
} 
offer the possibility of attaining higher states of concentration. Merely performing yoga postures will not serve the purpose. Understanding the states of mind is critical. Yoga denotes the cessation of mental functions known as "cittavttiniruddha."18 Consciousness has 19 mouths through which human experiences happen: speech, grasping, locomotion, reproduction, excretion, sight, hearing, smell, taste, touch, the 5 life principles, the mind (Manas ${ }^{19}$ ), the Intellect (Bhuddhi ${ }^{19}$ ), the Self-sense (Ahankara ${ }^{19}$ ), and the thinking organ (Citta). ${ }^{19}$ The interaction of trigunas with these organs creates Vrttis (fluctuations -- unverified knowledge, unreal knowledge, imagination, sleep and memory ${ }^{13}$ ), and Kleshas (disturbances -- ignorance of reality, egoism, attachment, hatred and fear of death ${ }^{13}$ ) which disturb the consciousness. Yoga is a journey that passes through the annamaya kosha (improper digestion), manonmaya kosha (lack of homeostasis), pranamaya kosha (haphazard flow of vital life), vijnanamaya kosha (intellectual disturbances), and anandamaya kosha (dissatisfaction with oneself). This leads us to asanas ${ }^{18}$ (steady yoga postures), mudras, ${ }^{20}$ and kriyas. ${ }^{21}$

In conjunction with breathing awareness (Pranayama ${ }^{18}$ ) asanas guide an adolescent along an effortless yoga journey toward a union of body and mind where all conflicts dissolve. Prana means not breathing. Mind and prana (vital life) are interrelated. ${ }^{18}$ Relaxation is indispensable and helps in the withdrawal of all senses to free one's mind from conflicts. This enables individuals to enjoy the current moment without being judgmental. To relax completely, the adolescent must detach themselves from their name and what they are known for. ${ }^{22}$ When children perform integrated yoga practice effectively, the purpose of education is served.

\section{western philosophical approach for school children - lipman}

Philosopher Matthew Lipman (USA) was so unhappy with the low-quality argumentation and reasoning skills he observed in school children that he devised the

\footnotetext{
${ }^{19}$ https://iep.utm.edu/sankhya/

${ }^{20}$ https://www.britannica.com/topic/mudra

${ }^{21}$ https://www.britannica.com/topic/kriya-yoga

22 https://yogainternational.com/article/view/the-importance-of-relaxation-training
} 
'philosophy for children' movement. This was the first movement of its kind in the Western world. He persuaded educators to teach logic to school children before they went to college. He found that he could stimulate an interest in philosophy among children aged 10-11 (concrete operational stage of Piaget). He launched his efforts through publication of his first children's novel, Harry Stottlemeier's Discovery (see Lipman, 1973). In the mid-1970s, he established the Institute for the Advancement of Philosophy for Children (IAPC) at Montclair State College (see Lipman, 2018). The philosophy for children (p4c) curriculum was written by Lipman and his team for schoolteachers with no formal training in philosophy. Thus, teachers who deliver p4c need not be philosophers. The curriculum consists of eight specially constructed philosophical novels with accompanying teacher manuals, each targeting a different age group (Murris, 2016).

Lipman felt that education inhibits the natural reasoning abilities of children.23It expects children to develop philosophical skills randomly and unconsciously, if at all. In a study of fifth-grade children, he also found that critical reading was taught unsystematically. Lipman wanted teachers to devise attractive methods of teaching critical thinking and allow children to discover how thought can impact upon its subject-matter. Students who are good at mathematics and the manipulation of symbols are fearful of the richness of language. Training in mathematics does not mean the child is assured of being trained successfully in logic (Lipman, 1973). A child trained in science would be able to make an inductive inference; however, formulating a meaningful hypothesis is not an easy task and cannot be achieved all the time within classrooms. Teachers may therefore be required to tailor specific learning situations to each child so that they can perform complex tasks. During reading classes, when teachers suggest one possible meaning for the reading, they do not allow the child to try out other possibilities. The rich connotations available are therefore not going to be understood by the child. In mathematics, problems are not taught systematically.

\footnotetext{
${ }^{23}$ https:/ / pdfs.semanticscholar.org/cf60/3d657d8992f4a3bd3675da8f0f91b570c987.pdf (1973, in references)
} 
Lipman challenged educators, arguing that just because the child's thinking is concrete does not mean instruction during this phase of development should also be concrete. He was unhappy with irresponsible television shows and child magazines that spoil children's minds and with schools' educational plans as they do not cultivate the intellect of the children. He contended that children should be taught to identify and handle a variety of life situations using different methods. Lipman also felt that children develop low self-esteem owing to their poor intellectual capacity and do not trust their peers. They do not understand the power of discovering ideas through dialogues and discussions. He also raised the point that physical education and hygiene are given a place in education, whereas mind education is not. He forcefully argued that if ethics could be taught in school, logic also should be taught. He stressed the need to make logical thinking in children habitual. Logic will only have value for the fifth-grade child if it is embedded in a context of ideas against which it can be constantly applied. These ideas are those considered important in the various fields of philosophy: ethics, political and social philosophy, aesthetics, metaphysics, and others (Lipman, 1973). Lipman asserted that it is erroneous to assume children are incapable of philosophical deliberation. Perhaps, in the real world, it is the children who constantly keep asking "why" questions. He opposed the didactic teaching of logic and wanted to teach logic to fifth-grade children through storytelling. Children need to conduct scientific experiments and lab activities but they also need to know how to determine whether the argument is valid or invalid. He considered this to be fundamentally important. Educators have underestimated the amount of preparation necessary to arouse a child's curiosity; Lipman therefore stressed the need to construct instructional materials and resources that contain an intellectual shock and surprise for the child. Based on these issues, he suggested using his story - Harry Stottlemeier's Discovery ${ }^{24}$ - to teach philosophy to children from class 5 to class 8 (Lipman, 1973).

${ }^{24}$ https:/ / files.eric.ed.gov/fulltext/ED103298.pdf (https:/ / eric.ed.gov/ ?id=ED103298) 


\section{comparison of philosophies of the west and the east}

Indian philosophy aims for the cessation of thoughts, ultimately bringing an individual to an end (sammadhi), whereas Western philosophy strives for the construction of an individual, the harvesting of a child's curiosity, and accelerating thoughts. The former could ultimately lead to unification and oneness, whereas the latter could lead to the increased fragmentation of consciousness (Bohm, 1981). Logic is a smaller subset of philosophical teaching in India, whereas it is the main tool of Western philosophy.

In Indian philosophy, the intellect is the faculty of the mind. Importantly, intellectual development proceeds after establishing control over one's thoughts. Intelligence and wisdom are therefore given more scope than intellect. By contrast, among their Western counterparts, intellect is given higher weighting in the construction of knowledge. Although Socrates was known for his wisdom, what became popular out of the philosophical thought and logic he espoused was science and technology. Technology and business have always overpowered wisdom. Through proper reasoning, overall human development is possible. Even though fluctuations in the mind can be controlled through careful reasoning processes, this does not succeed in arresting all animal desires at all times. When one's desires are greater, the territories of the mind expand. Thoughts that arise in one person become part of another person's mind. It may therefore be the case that the boundary of an individual's mind can never be defined. Buddhism and Jainism from India advocated teaching Nihilism in schools, especially to young adolescents. Sextus Empiricus, Phyrrho, and David Hume (from the West) propounded skeptical philosophy which could be introduced to school children.

Yogic postures are effective only through control of the mind and breath (Pranayama). In Western circles, breathing techniques are not integrated into understanding the self. On the contrary, reasoning is critical to self-awareness. Ramayana, Mahabharata, Puranas, and Panchatantra developed rich stories through which ethics can be taught. They also indirectly taught epistemology and the skills of 
dialectic argument. The Iliad and the Odyssey are the main epics of the West and feature heroic men who exhibit valor in the face of devils and bring them to their feet. By contrast, p4c has an entirely different storytelling strategy.

Specifically, Indian education is a teacher-centric method where students listen to the information transmitted by an elder teacher (Gurukula or modern schools). By contrast, in Western schools, students sit together to deliberate over a particular philosophical theme, arguing skillfully and slowly until they reach common ground before they are dispersed. In Panchatantra, a conclusion is drawn after a story is told by the teacher to students. In the Western method, students are asked to reason for themselves in order to draw a conclusion. In ancient India, education was not recommended until 5 years of age. It was thought that one should upbring a child with love and utmost care during the initial five years, followed by the maintenance of strict discipline over the next ten years. Once the child reaches the age of sixteen, they should be treated like a friend. Philosophy was taught after upanayanam, a formal admission ceremony when the child becomes 8 years of age. Among their Western counterparts, Piaget suggests educators should tailor the child's education to conform to the phases of his/her cognitive development. However, Lipman argued against this and advocated $\mathrm{p} 4 \mathrm{c}$ as a means to accelerating thinking. The teaching method is nonauthoritarian and the child is given full freedom to inquire. Bruner's research also showed that an extremely young child is capable of learning any material so long as the instruction material is organized. ${ }^{25}$ Indeed, modern India sends children to playschool at age 3 (Indian National Education Policy, 2020).

In yogic philosophy, thoughts are linked to breathing. Students are taught breathing practice by being asked to memorize and repeat hymns. In the West, thoughts are monitored without making any checks on one's breathing. The structure of thought is examined using logic and rationality. Buddha propounded the eight noble truths which, in order, are rightness in view, intention, speech, conduct, livelihood, effort, mindfulness, and samadhi (cessation of an individual). Their Western

${ }^{25}$ https://www.britannica.com/biography/Jerome-Bruner 
counterparts prescribe the same but without any specific order. The West does not make any specification regarding the cessation of thoughts. When learning Indian philosophy, adolescents may be taught to focus on karma and reincarnation and then think along those lines. When learning Western philosophy, adolescents are taught to live ethically in their current lifetime drawing on values such as love, tolerance, humanity, and empathy.

In the Indian approach, Panchatantra stories use animal characters to teach ethics to children. Logic and reasoning techniques are not directly focused upon. What is 'right' and what is 'wrong' are revealed at the end of the story. In the West, children have to discuss a central topic and draw conclusions that are commonly accepted by a group. Piaget uses the word "animism" in relation to the pre-operational stage of cognitive development (2-7 years) wherein the child believes that inanimate objects (such as toys and teddy bears) have human feelings and intentions, and cannot use logic or transform, combine, or separate ideas. Lipman argues that if children aged 912 cannot understand formal logic, then teachers must formulate strategies to induce formal logic learning in adolescents to accelerate their thinking (see Lipman, 1973). Education in ancient India taught philosophy free of charge. The students served the teacher (Guru), begged for alms, and cooked food for the guru who was like a father to the student. Begging was considered noble in ancient India; indeed, Buddha also begged. In modern India, philosophy is not taught to children in schools, whereas science and mathematics are taught directly. The Indian national curriculum framework does not have sufficient scope to teach philosophy, except for when science is taught (Ex: scientific method). In both the East and the West, education has become a business. Yoga has already been commercialized as part of a spiritual supermarket.

Although Western and Indian philosophies have argued about the same problems and developed similar theories, there have also been marked differences between them. Indian psychomedical thought believed that the human body is made up of vatha, pitta, and Kufa (body fluids), whereas Hippocrates' theory stated that human bodies are made of fluids and four humors - sanguine, phlegmatic, choleric, 
the conundrum in the collective indian psyche regarding teaching philosophy in schools

and melancholic. The differences between them lay in the origin (utpatti) and apprehension (jnapti) of truth (pramanya). Western philosophy addressed the question of whether knowledge arises from experience (empiricism) or from reason (rationalism) and made distinctions such as those between analytic and synthetic judgments or between contingent and necessary truths. Their Indian counterparts did not travel so deeply into such areas. Indian thought therefore provides historical perspectives that supplement Western philosophy and ascertains certain philosophical developments that took place later in Western thinking. A study of Indian thought reveals insights that Western philosophical thought lacks. ${ }^{26}$

Indian philosophy questions the existence of the questioner. It therefore contrasts with Rene Descartes's words "I think, therefore I am". It matters if an individual exists and this becomes the birthplace of logic and intellect. It also matters or does not matter if an individual does not exist and that marks the end of the individual and hence ends the problems of philosophy. We can only observe that there is a meaning acquired when the individual is assumed to exist or is subjected to cessation. These parts are best addressed by Wittgenstein, as follows:

"We feel that even when all possible scientific questions have been answered, the problems of life remain completely untouched. Of course, there are then no questions left, and this itself is the answer." (Tractatus-6.52).

"The solution of the problem of life is seen in the vanishing of the problem. (Is not this the reason why those who have found after a long period of doubt that the sense of life became clear to them have then been unable to say what constituted that sense?)" (Tractatus-6.521, Wittgenstein)

Indian philosophers have also acquired knowledge from modern developments in Western philosophy. ${ }^{26}$ As Wittgenstein contends, when questions are not there, thoughts should come to an end and that is the "Niruddha" (still mind state) uttered by Indian saints. Which is correct - the Indian or Western view of philosophy? This essay does not focus on the divide but emphasizes that the education materializes through self-awareness. We recollect the words of Socrates: "An unexamined life is not

${ }^{26}$ https:/ / www.britannica.com/topic/Indian-philosophy\#ref20638 
worth living". When there is no self-awareness, ignorance prevails, manipulates, and destroys. This is evidenced by the way in which we are living right now amidst the COVID-19 pandemic.

\section{the east-west dilemma in teaching philosophy in schools}

When we read Mathew Lipman, we find that his focus is mostly on increasing children's curiosity, thinking about children's thinking, accelerating this thinking process, teaching logic and formal reasoning in pre-formal years of cognitive development using an appropriate pedagogy for philosophy, intellectual enhancement, free-thinking, discovery thinking, and philosophical deliberation through storytelling.

Conversely, David Bohm (Bohm \& Park, 1981) describes "fragmentation and wholeness" as an important issue that is widespread in society and within individuals - this has resulted in the fragmentation of academic knowledge and consciousness. Bohm states that science is supposed to examine a problem holistically but instead has broken it down into physics, chemistry, and biology ${ }^{27}$. Physics has been broken down further into areas such as nuclear physics, biology into zoology, and botany, and chemistry into organic and inorganic chemistry, generating a multitude of interdisciplinary disciplines that search for universal truth (Policy 11.11, Indian National Education Policy, 202028). Researchers dissatisfied with solutions therefore keep creating new problems and solutions. Externally, society as a whole has been segmented into individual countries, provinces, and districts, leading to border disputes, and different religious, political, economic, racial, and linguistic groups that exploit the natural environment as each imagine they are separate entities. Internally, each individual has been fragmented into conflicting parts according to his/her desires, aims, ambitions, loyalties, psychological characteristics, and others, such that

\footnotetext{
${ }^{27}$ http://www.gci.org.uk/Documents/DavidBohm-WholenessAndTheImplicateOrder.pdf

28 https://www.mhrd.gov.in/sites/upload_files/mhrd/files/NEP_Final_English_0.pdf (The words holistic education and multidisciplinary education are conflicting in nature. Holistic knowledge implies Godliness, the all-knowing)
} 
some degree of neurosis cannot be avoided. While some of the population are fragmented and appear to themselves as individuals with personal problems, some go beyond normal limits of fragmentation and are classified as paranoid, schizoid, and psychotic (a view supported by Sagar, Dandona, Gururaj, .... Dandona, 2020).29 The perception that an individual separately exists is an illusion and will lead to endless stress and strife in life. It has also led to a succession of extremely urgent crises in the shape of pollution, destruction of the natural order, over-population, world-wide economic and political disorder, and the creation of an overall environment that is not physically or mentally healthy for people. There is an overall sense of helplessness felt across this planet by all human beings (Bohm, 1981).

The current curriculum (constructivism) at schools helps children explore the world and construct knowledge without considering the view that the broken fragments of the individual (ego) are trying to construct the whole. In many ways, it is not concerned with acquiring true knowledge. Instead, it prepares students for work in industry to boost the national economy and support their families. Such a scenario cannot endure for long owing to the uncertainty of knowledge ${ }^{30}$ (as during the COVID19 pandemic). Artificial intelligence and machine learning are now buzzwords in the academic world and have implications for people's future lives. Mechanization has now grown to the extent that individuals have lost control of their ways of living in multiple realms. Food quality and health, for example, are governed elsewhere. Robots are said to be a future replacement for classroom teachers.

In the West, self-realization is viewed as a way to construct a better individual. Indian philosophy has always emphasized the cessation of an individual and focused on an incomprehensible truth that human languages cannot capture.

"The limits of my language mean limits of my world" (Tractatus 5.6). "Whereof one cannot speak about thereof must pass over in silence" (Tractatus 7.0) - Wittgenstein.

\footnotetext{
${ }^{29}$ The article can be retrieved - https://www.thelancet.com/action/showPdf?pii=S2215$0366 \% 2819 \% 2930475-4$

${ }^{30} \mathrm{http}: / /$ www.bbc.com/earth/story/20170504-there-are-diseases-hidden-in-ice-and-they-are-wakingup
} 
Western philosophy has focused on questioning, inquiry, and the problems of philosophy. The East is concerned with bringing such questioning to an end (Wittgenstein, Tractatus logico Philosophicus). Although it encountered subjugation by British colonization and conquests by the Mughal Empire, the collective Indian psyche, has staunchly held on to its ancient belief system. Indians are now Westernized; they have adapted themselves to the Western extravaganza of life but, deep down inside, they believe in self-realization and their own Gods without ever being fully aware that they are caught up in a life that is dragging them into two extreme corners. They take pride in such a fashioned life. I have always wondered about this contradictory life that people lead but the Indian masses seem very comfortable living such a life. The problem becomes evident when I focus on the nature of philosophy education that I could offer to school children.

Existing Indian schools rarely teach yoga seriously and their focus is on the perfection of asana postures, rather than emphasizing the importance of mind control. Numerous schools use physical training periods to teach asanas. Yoga is offered as a minute constituent of a vocational course in higher secondary schools. Yoga and meditation are not part of mainstream courses because school management teams wish to maintain the support of their customers (parents) by offering coaching only in mathematics and sciences so that the children can become doctors or engineers and earn a considerable income for their respective families.

The educational objectives and assessments in India's National Council for Educational Research and Training (see NCERT, 2015) colorful and appealing school textbook on yoga ${ }^{31}$ include test items at the remembering and understanding level (lower-order thinking skills) of Benjamin Bloom's taxonomy of educational objectives. The project question items are focused on the skill of drawing, rather than the skill of

\footnotetext{
31 https:// zietmysoredigtallibrary.files.wordpress.com/2016/06/yoga-1.pdf (NCERT. (2015). Yoga -A healthy way of living Upper Primary Stage. National Council of Educational Research and Training. (A similar textbook was published by NCERT for the secondary stage.)
} 
performing yoga. In the yoga Olympiad pamphlet ${ }^{32}$ (see NCERT, 2019), more emphasis is given to perfecting the asana postures than controlling the mind ${ }^{32}$. Careful scrutiny of the assessment rubric indicates that it does not assess control of the mind. Indian ethics and character formation is part of India's Central Board of Secondary Education's (CBSE) Class XII textbook. Moreover, the Class XII book is available only in the Hindi language and is a vocational option subject that has now been discontinued. India has 22 official languages as per schedule VIII of its constitution. The 21 languages (sans Hindi) are spoken by the vast majority of the population. The only vocational study option available in Class XII is part-C "Yoga Anatomy \& Physiology" 33 under the vocational option "Health Care and Beauty Culture." 34 This indicates that, with a few exceptions, yoga is not taught seriously in Indian schools and there is no real understanding of the art. India is struggling with corruption and other problems, simply because its education system does not produce quality citizens.

\section{the collective indian psyche regarding philosophy}

Indian parents are the decision-makers regarding their children's education, career, and lives (arranged marriages, for example). If philosophy is needed for children in school, then it is imperative to understand their beliefs, collective psyche, and the complex functionalities of their lives. Today, the rich and the middle class can provide an education for their children that is geared toward scoring high marks fulfilling the current needs of society. The schools are also interested in showcasing these marks without any concern for children's development. Showcasing academic marks helps individuals move toward "success" -- a human-made concept. Yoga strives to disregard one's name and renown. However, parents are proud of their sons and daughters living in rich developed countries, yet want to preserve their Indian

\footnotetext{
32 https://ncert.nic.in/dess/pdf/GuidelinesforYogaOlympiad-Final.pdf (Check table 1, 2, 3, 4, 5 - The word "mind" is missing in the document meaning more importance is given to postures and asanas. Is mind hidden? - NCERT. (2016). Yoga Olympiad 2016 Scheme and general Guidelines)

${ }^{33} \mathrm{http}$ ///cbse.nic.in/newsite/Vocational/SYLLABUS_HEALTHNBEAUTY.PDF

${ }^{34}$ https://www.thehindu.com/society/why-is-yoga-being-sexualised/article32315984.ece
} 
culture. Children of poor parents do not have proper access to education. If they have access at all, this is a basic literacy education in local languages. However, local languages do not produce contemporary-world literature. Children that become extremely well-educated use only their intellect; they are not fully developed physically, mentally, psychologically, emotionally, aesthetically, or otherwise. We see numerous students commit suicide ${ }^{35}$ because of academic pressure and this includes students from top-ranked educational institutions. Children with a high IQ may use their intellect to hack secure systems or create products more dangerous for society. The reason for such tragic outcomes is the lack of value education at schools. There are teaching periods for moral science, Bhagawat Gita, Koran, and Bible in schools in India. In the morning, following the national policy of education 1986 guidelines, schools provide space for children to pray and assemble to conduct moral and ethical preaching. However, this does not seem to be effective, primarily for the reason that the values are artificially preached without the student understanding the implications. Axiology is the branch of philosophy that considers the study of principles and values (ethical or aesthetical). Current education promotes competition, success, and progress without giving space for children to question the meaning of these terms. Can teaching axiology or yoga solve the collective conundrum that is taking society down the wrong path?

Would today's Indian parents be interested in the Niruddha (still mind) of their children, which is said to be the highest state of mind where consciousness ceases to move? Do the parents want their child to be a Buddha boy or a successful businessman? Such research would seem to be less important in today's fast-paced life where the aim is always to seek opportunities to enhance the economy. Contemporary parents want yoga to be a supporting agent that can enhance the academic performance of students. This is exemplified by the fact that Indian research papers on yoga stereotypically examine the relationship between yoga, meditation, and securing high marks in exams.

35 https://www.businessinsider.in/india/news/60-students-committed-suicide-at-iits-and-iims-inthe-last-five-years/articleshow/72364361.cms 
the conundrum in the collective indian psyche regarding teaching philosophy in schools

Marks are considered more important than the satisfaction of academic accomplishment or the love of learning a subject, as reiterated by popular Bollywood movies Taare Zameen Par ${ }^{36}$ and 3 Idiots. ${ }^{37}$

Yoga is widely accepted as something that is good for a healthy stress-free life. Parents put children in a yoga class for this purpose. It is often forgotten that such a stressful life pattern has arisen out of the need to compete with fellow human beings. Students may feel resentment and anger if they receive lower marks than their friends. Parents of students are interested in the higher-order thinking skills (intellect) as evidenced by their desire to see their children succeed in national entrance exams (example: Indian Institute of Technology-Joint Entrance Exams, Union Public Service Commission exams) and other competitive exams. Yet, at the same time, there is a modern craze among parents to compel their children to learn yoga in order to preserve Indian culture and traditions. Preserving ancient yogic culture is commendable, but not when it involves misinterpreting the meaning and significance of yoga. People want to pursue yoga because it is said to increase longevity, whereas the actual intention of yoga is to enable people to live comfortably in the present. Longevity implies 'thoughts' directed toward the future. Indians are not interested in preserving their tradition based on its merit, nor do they follow the rigid values of Western systems. According to the World Happiness Index 2020, the majority of Indians today are not happy. ${ }^{38}$ India ranks $144^{\text {th }}$ on the index, the lowest ranked country being Afghanistan $\left(186^{\text {th }}\right)$. The purpose of yoga as an art has been lost. Introspection is important to overcome a collective psyche that is heading in a negative direction. Western countries have substantially more money and resources, and their citizens ultimately - seem to live much more happily (Finland) than Indians ${ }^{39}$ Should Indian schools therefore teach in the manner recommended by Lipman?

\footnotetext{
36 https://www.imdb.com/title/tt0986264/ (taarae zameen par movie)

37 https://www.imdb.com/title/tt1187043/ (3 idiots movie)

38 https:/ / worldhappiness.report/ed/2020/ (world happiness index report 2020)

${ }^{39}$ https://www.dailymail.co.uk/travel/travel_news/article-8134109/The-worlds-happiest-countriesrevealed-Finland-keeps-spot.html
} 
Yoga helps people to live in the present in a relaxed manner. Erik Erikson (see Kroger, 2004) famously claimed that adolescent life is filled with stress and strife, but most of the stress has been added to people's lives by the systems in which they live and their present values, which are to pursue success, money, and fame. Modern-day Indians are now caught between the need to preserve the ancient traditions and clinging on to these existing systems, and this morass of contradictions and confusion is what governs their day-to-day lives. Ancient yoga education through the Gurukula method was full-time as it involved the student staying with the teacher and learning under him. By contrast, contemporary parents prefer part-time yoga, which may not succeed as any useful human skill demands a lengthy period of practice. Furthermore, when it comes to controlling the mind through yoga, a more earnest effort is required for which society does not currently provide sufficient scope. It also means yogic arts and sciences are not taken seriously in schools, whereas in ancient days, around the age of 8 , an admission ceremony was performed, and studies involved philosophy at the Gurukula school.

Although Sammadhi (Niruddha) is said to be the highest achievement in Indian philosophy, there are currently no proponents of Indian philosophy who could successfully demonstrate attaining such a state. Sages who have transcended or stumbled into such situations may claim that their state of being cannot be put into words in any form of human language as it cannot be explained in the realm of knowledge obtained through experiences. Truth becomes corrupted when an attempt is made to capture it in human languages. Rao (2015) makes every effort to describe such a self-realized state on a purely biological basis ${ }^{40}$ to avoid sounding obscure or fuzzy. This could also have been the reason why - for a long time -Vedas were not written in text (see Sweetman, 2019).

\footnotetext{
${ }^{40}$ https:// books.google.co.in/books/about/Biology_Of_Enlightenment.html?id=EFQOI25tLlQC\&redi $\underline{r}$ esc $=y$ (Click the title page picture to view parts of the book).
} 


\section{reconsidering the global psyche?}

I have explained that the collective Indian psyche is entangled in a conundrum. So far in the West there seems to be no rudimentary dilemma regarding approaches to teaching children philosophy, and Lipman's curriculum is now being tested in numerous countries. Even in Indian schools, there are reports of p4c being a success (see Mehta \& Whitebread, 2004). However, can the West easily omit the original Indian ideology of Niruddha while teaching philosophy to children? Are we, as citizens of the world, open to considering all the perspectives philosophy can offer while living this life? Several Western countries live happily, compared with India, but humanity as a whole keeps living under constant stress. These dangerous problems are the outcomes of the intellect that $\mathrm{p} 4 \mathrm{c}$ strives to sharpen in children. The products of $\mathrm{p} 4 \mathrm{c}$ will be mature citizens but, when working together in a society, it is difficult to envisage a single day where intellect does not cause global or local problems. The thought process does not allow us to think holistically (i.e., see the bigger picture) with the result that human activities are often transformed into environmental problems. For example, a wood merchant is interested only in supplying good quality timber to his clients; he does not consider the environmental effects of cutting down trees. Hence, there is an extremely important question that needs to be answered: Should we accelerate or decelerate the thoughts of children by teaching philosophy at schools?

Educational objectives cutting across the curriculums of the world have always assumed that life is meaningful. However, when people focus on only one possibility for life, they are unable to envisage an alternative possibility that says, "life may not have any meaning or sense at all". Perhaps when people assume that "life is always meaningful", they tend to think that they must do something to preserve this meaning. Hence, people have focused on coloring life, which has resulted in arrogance, atrocity, and environmental damage. A fair world is possible through a philosophy curriculum that provides children with a broad menu of possibilities. How can holistic education be discussed when an immense truth (that life may not have any meaning) is hidden or omitted from the curriculum? One may argue that having an educational foundation 
in "no meaning" would be absurd and problematic. I respond to this by explaining that Indians have lived this way in the past. Indians taught the world the method of counting numbers by introducing zero (shoonya). What could have been the inspiration for this? It could have been 'nothingness.' Life can be meaningful or meaningless - it is a philosophical pursuit. The educational objectives of the curriculum should reflect both of these possibilities. India has taught skeptic philosophy to children at Gurukula schools; however, in the contemporary world, the death of loved ones is seen as something alarming. I am not undermining the value of observing condolences for the death of a loved one but death may not necessarily be associated with sorrow. There are other possible ways of living that people may be denying themselves access to.

Putting these ideas together, I feel that logic and reasoning need to be taught in schools as does integrated yoga practice, the goal of which is to attain the Niruddha (a still mind state that has no goal in mind). A combination of both could be the way forward in creating a livable world. It makes more sense to teach other subjects after or in parallel to teaching philosophy. The child would then grasp knowledge from multiple sources effortlessly and with humility. I am suggesting an experimental route in education; however, if the outcomes are not encouraging, then I will be rightly subjected to criticism. Whether or not my idea is accepted someday and taken forward, I would like to end this essay by arguing that philosophy must be taught in schools because any education without self-analysis is potentially destructive to individuals, society, and the wider world.*

\section{references}

Aranya, S. H. (2000). Yoga philosophy of Patanjali with Bhasvati. Calcutta: University of Calcutta, ISBN: 81-87594-00-4

Bohm, D., \& Park, D. (1981). Wholeness and the Implicate Order. American Journal of Physics, 49(8), 796-797

Bohm, D. (1994). Thought as A System. London: Routledge.

Iyengar, B. K. S. (1996). Light on the Yoga Sutras of Patanjali. Philosophy East and West, Thorsons.

Kroger, J. (2004). Identity in Adolescence: The Balance Between Self and Other. Routledge: London \& New York 
the conundrum in the collective indian psyche regarding teaching philosophy in schools

Lipman, M. (1976). Excerpts from Harry Stottlemeier's discovery. Metaphilosophy, 7 (1), 40-52.

McEvilley, T. (2002). The shape of ancient thought: Comparative studies in Greek and Indian philosophies. New York: Allworth Press.

Mehta, S., \& Whitebread, D. (2004). Philosophy for Children and moral development in the Indian context. First Global Conference on Philosophy with Children, 2004.

Murris, K. (2016). The Philosophy for Children Curriculum: Resisting 'Teacher Proof' Texts and the Formation of the Ideal Philosopher Child. Studies in Philosophy and Education, 35, 6378

Radhakrishnan, S. \& Moore, C. A. (1960). A Source Book in Indian Philosophy, Princeton University Press.

Ramanasramam., S. (1999). Yoga Vasistha Sara. Y.S Raman. Tirvannamalai, South India.

Rao, M. (2015). The Biology of Enlightenment. HarperCollins.

Roeser, R. W. (2005). An introduction to Hindu India's contemplative psychological perspective on motivation, self, and development. Religion and Motivation, 14, 97-345.

Sagar, R., Dandona, R., Gururaj, G., Dhaliwal, R. S., Singh, A., Ferrari, A., Dua, T., Ganguli, A., Varghese, M., Chakma, J. K., Kumar, G. A., Shaji, K. S., Ambekar, A., Rangaswamy, T., Vijayakumar, L., Agarwal, V., Krishnankutty, R. P., Bhatia, R., Charlson, F., ... Dandona, L. (2020). The burden of mental disorders across the states of India: the Global Burden of Disease Study 1990-2017. The Lancet Psychiatry, 7(2), 148-161.

Shruthi, K.R., \& Rajani Jairam. (2016). Role of Subhashitas in creating a model society. International Journal of Education \& Applied Sciences Research, 3(3), 41-50.

Srinivasan, T.M (2015). Vedic Yoga: The Path of the Rishi. International Journal of Yoga, 8(2), 166167

Sweetman, W. (2019). The Absent Vedas. Journal of the American Oriental Society, 139(4), 781803.

Wittgenstein, L. (1922). Tractatus logico-philosophicus. London: Routledge \& Kegan Paul.

received in: 05.08.2020

approved in: 29.09 .2020

\footnotetext{
* The views expressed in this article are that of the Author and not the organization Amrita Vishwa Vidyapeetham, India.
} 